\title{
ALTERNATIVE FOAMING AGENTS FOR FABRICATION OF GLASS FOAM
}

\author{
Ildikó Fóris \\ PhD student, University of Miskolc, Institute of Raw Material Preparation and Environmental Processing \\ 3515 Miskolc, Miskolc-Egyetemváros, e-mail: ejtforis@uni-miskolc.hu \\ Gábor Mucsi \\ professor, University of Miskolc, Institute of Raw Material Preparation and Environmental Processing \\ 3515 Miskolc, Miskolc-Egyetemvásor, e-mail: ejtmucsi@uni-miskolc.hu
}

\begin{abstract}
Glass foam tablets were produced from container glass bottles (CGB) using eggshell waste (ESW) and perlite $(P)$ as foaming agent in different portions. The ground raw materials (CGB, ESW, P) were homogenized and pressed with hydraulic piston press machine at different pressures (in the case of $P$ containing tablets $30 \mathrm{MPa}$ and ESW containing tablets $15 \mathrm{MPa}, 30 \mathrm{MPa}$ and $40 \mathrm{MPa}$ were used).The obtained glass tablets were heat treated at different temperatures (in the case of $P$ containing tablets $800{ }^{\circ} \mathrm{C}, 900^{\circ} \mathrm{C}, 1000^{\circ} \mathrm{C}$ and $1100^{\circ} \mathrm{C}$, and ESW containing tablets $600^{\circ} \mathrm{C}, 700^{\circ} \mathrm{C}, 800^{\circ} \mathrm{C}$ and $900{ }^{\circ} \mathrm{C}$ were used). The study shows the specimen density of tablets before and after heat treatment, as well as the true density of the powder mixtures before tableting and the abrasion resistance of the glass foam products.
\end{abstract}

Keywords: recycling, glass foam, glass waste, eggshell waste, perlite

\section{Introduction}

According to the Circular Economy Directive set by the European Union, $85 \%$ of glass waste must be recycled by 2030. In Hungary, this rate is much lower, based on the latest known data, this value is $36 \%$. The problem in Hungary is caused, among other things, by the fact that there is no domestic glass factory that would accept the generated glass waste amount; in addition, glass waste which is processed in its material structure with other types of materials, such as textiles, paper is not recycled (Kálnai and Kálnai, 2007).

Glass foam is one way of recycling glass that can be fully incorporated into the circular economy method. In addition to glass recycling, other wastes can be recycled also, as an additional material to glass foams, creating high value-added products with less energy consumption and raw material use. Glass foams are porous materials $(>60 \%)$ of gas and solid phase, which are well-suited for a wide range of applications in the field of construction, for example for the insulation of roofs, walls, floors, ceilings as a light aggregate in concrete or even as a filler for restoration of failed slopes (Scheffler et al., 2006, Scarinci et al. 2005).

The goal of this paper is to produce high-added-value products with low-cost raw materials such as recycled glass bottles, eggshell waste and perlite. 


\section{Methods}

Glasses from container glass bottles (CGB) of different colors (green, brown and white) were used as raw materials. Eggshell waste (ESW) and perlite (P) were utilized as foaming agent and Na-bentonite used as a binder material. There is a significant stock of perlite in Hungary; which has been mined in Pálháza since 1958, and is one of the effusive rocks, characterized by the glassy modification of rhyolite (Farkas, 2001). A special property of perlite is that it swells to 7-16 times its original volume when heated to $800-1100{ }^{\circ} \mathrm{C}$, and this property was applied to foam the glass tablets. The main constituent of the eggshell is calcium carbonate (94-96 wt\%), which is present in crystalline form as calcite. It also contains calcium phosphate (about 1\%), magnesium phosphate (about $1 \mathrm{wt} \%$ ), and other organic substances (4 wt\%) (Baláž, 2018). Due to the carbonate content of the eggshell, it is suitable for foaming, as $\mathrm{CO}_{2}$ is released during thermal decomposition of calcium-carbonate, which leads to the formation of the porous structure.

CGB were pre-crushed in a hammer crusher with a screen size of $1 \mathrm{~mm}$, and then dry-milled in a ball mill using stainless steel balls for $180 \mathrm{~min}$ to achieve the $<50 \mu \mathrm{m}$ particle size of the glass powder. The ESW was milled using a planetary mill for $10 \mathrm{~min}$. No grinding was required for perlite and Na-bentonite because their particle size were in fine size range.

Moreover, in the case of ESW, it was necessary to remove the organic matter before grinding, which was achieved by heat treatment in boiling water for 30 minutes.

Chemical compositions of CGB and ESW were obtained by X-ray fluorescence (XRF) analysis. The particle size distribution measurement of the raw materials was carried out with HORIBA 950 LA laser diffraction particle size analyzer.

Each raw material was sieved using a sieve with $32 \mu \mathrm{m}$ opening sizes under wet conditions. This was necessary for each material to fall in almost the same size range, so the structure of the finished glass foam tablets was more homogeneous.

In both cases, the foaming agents were added to the glass powder in different ratios, and in each case contained $2.5 \%$ Na-bentonite as a binder material. All tablets were $10 \mathrm{~g}$, and after homogenization of the mixture, were prepared using hydraulic piston press at different pressures. The proper pressure was $30 \mathrm{MPa}$ for $\mathrm{P}$ containing tablets and $15 \mathrm{MPa}$ for ESW.

The following foaming agent ratios were used for P-containing tablets: 0- 25-75-100 wt\%. In the case of ESW-containing tablets, the following ratios were determined from a comparison of several literature examples (Fernandes et al., 2014; Zhong et al., 2010; Li et al., 2018; Souza et al. 2017): 10$20-30 \mathrm{wt} \%$. In further experiments, the proportions were narrowed to $35-50 \%$ for $\mathrm{P}$ and $1-10 \%$ for ESW.

The obtained green tablets were heat treated in Nabertherm L (T) 3 laboratory static furnace in a range of $600{ }^{\circ} \mathrm{C}-1100{ }^{\circ} \mathrm{C}$ with different residence durations using a heating rate of $7-12{ }^{\circ} \mathrm{C} / \mathrm{min}$, which was found to be adequate for tablets foamed with P and ESW.

Controlling the heating rate of the furnace is extremely important to optimize the glass foam product. As a result of the rapid change in temperature $\left(40{ }^{\circ} \mathrm{C} / \mathrm{min}\right)$, large cracks form in the glass structure. The heating rate of $5-10{ }^{\circ} \mathrm{C} / \mathrm{min}$ can be used generally without problems. Furthermore, if the heating rate is too slow also harms glass foam, as prolonged isothermal heating at high temperature can lead to the premature generation of gases (Scarinci et al., 2005).

The true density $\left(\rho_{t}\right)$ of the powdered mixture (powder glass+ foaming agent + binder material) was determined by using pycnometer with isopropyl alcohol $\left(\rho=0.79 \mathrm{~g} / \mathrm{cm}^{3}\right)$ as liquid medium. 
The specimen density $\left(\rho_{s}\right)$ of the tablets before heat treatment was determined by their geometrical measurements, using a caliper and their masses with analytical balance. After heat treatment the specimen densities of the tablets were determined by using Archimedes' principle with fine-grained sand (P-containing tablets) and distilled water (ESW-containing tablets) as medium.

The porosity of the heat treated glass foam tablets was calculated from specimen density $\left(\rho_{\mathrm{s}}\right)$ and true density $\left(\rho_{t}\right)$ measurements according to the Eq. $(1)$, where $P_{0}$ is porosity $(\%), \rho_{s}$ is specimen density and $\rho_{\mathrm{t}}$ is true density.

$$
\mathrm{P}_{0}=\left(1-\frac{\rho_{\mathrm{s}}}{\rho_{\mathrm{t}}}\right) * 100
$$

The abrasion resistance of glass foam tablets was measured with cylindrical mill. $30 \mathrm{~g}$ from each ratio were tested in case of $\mathrm{P}$ and ESW-containing tablets. The 30 grams of material remained in the machine at $30 \mathrm{rpm}$ for 10 minutes, and after removing the material, the fine fraction was sieved using a $1 \mathrm{~mm}$ sieve. From the mass of the fine fraction and the feeding material, the degree of abrasion was calculated using Eq. (2), where $\Delta \mathrm{m}_{\mathrm{abr}}$ is the amount of abrasion (\%), $\mathrm{m}_{\text {fine }}$ is the amount of material passed through the $1 \mathrm{~mm}$ sieve $(\mathrm{g})$, and $\mathrm{m}_{\text {feed }}$ is the feeding material $(30 \mathrm{~g})$.

$$
\Delta \mathrm{m}_{\mathrm{abr}}=\frac{m_{\text {fine }}}{m_{\text {feed }}} * 100[\%]
$$

\section{Results and discussion}

\subsection{Characterization of raw materials}

Table shows the results of chemical analysis of the CGB and ESW obtained by X-ray fluorescence analysis.

Table 1. Chemical composition of ESW and CGB

\begin{tabular}{|c|c|c|c|c|c|c|c|c|c|c|c|c|c|}
\hline & $\mathrm{SiO}_{2}$ & $\mathrm{Al}_{2} \mathrm{O}_{3}$ & $\mathrm{MgO}$ & $\mathrm{CaO}$ & $\mathrm{Na}_{2} \mathrm{O}$ & $\mathrm{K}_{2} \mathrm{O}$ & $\mathrm{Fe}_{2} \mathrm{O}$ & $\mathrm{MnO}$ & $\mathrm{TiO}_{2}$ & $\mathrm{P}_{2} \mathrm{O}_{5}$ & $\mathrm{~S}$ & $\boldsymbol{F}$ & $\mathrm{LOI}$ \\
\hline Unit & $\mathrm{wt} \%$ & $\mathrm{wt} \%$ & $\mathrm{wt} \%$ & $\mathrm{wt} \%$ & $\mathrm{wt} \%$ & $\mathrm{wt} \%$ & wt\% & wt\% & wt\% & wt\% & wt\% & wt\% & $\%$ \\
\hline ESW & 0.3 & 0.0 & 0.62 & 54.4 & 0.13 & 0.13 & 0.03 & 0.001 & 0.002 & 0.499 & 0.21 & $<0.3$ & 43.06 \\
\hline CGB & 73.6 & 1.2 & 2.25 & 9.89 & 11.9 & 0.62 & 0.47 & 0.008 & 0.049 & 0.014 & 0.20 & $<0.3$ & - \\
\hline
\end{tabular}

The chemical composition of the glass showed that these are typical soda-lime glasses which used to manufacture bottles. The ESW composed mainly of calcium carbonate $\left(\mathrm{CaCO}_{3}\right)$. In case of ESW loss on ignition (LOI) was $43.06 \%$. 


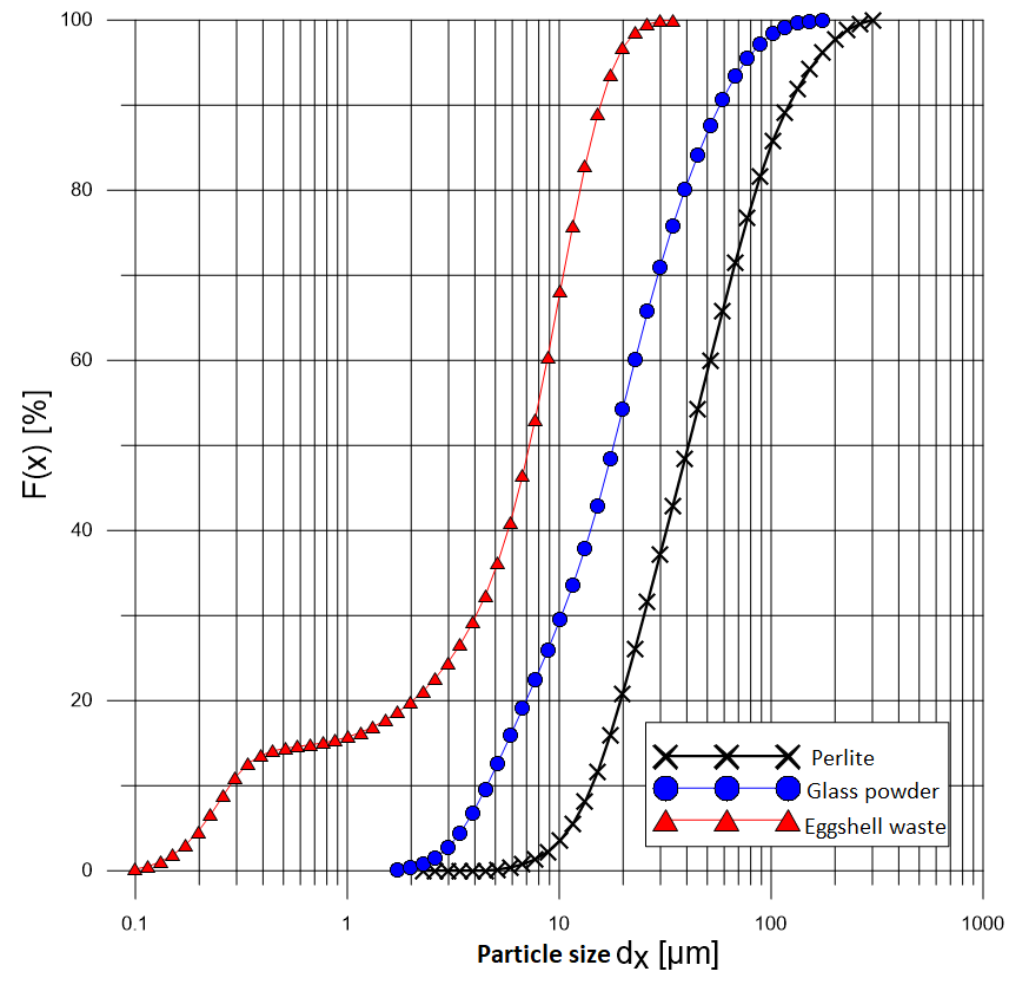

Figure 1 shows the particle size distribution of CGB, ESW after milling and P determined by laser diffraction particle size analyzer (Horiba LA).

The analysis designated (Table 2 ) that CGB, after crushing and milling process, had an median particle size $\left(\mathrm{X}_{50}\right)$ of about $12.32 \mu \mathrm{m}$, ESW had $7.78 \mu \mathrm{m}$ and $\mathrm{P}$ had $7.22 \mu \mathrm{m}$.

One of the most important steps in preparing raw materials is to achieve the appropriate particle size. It is necessary to crush the glass below $0.4 \mathrm{~mm}$, otherwise the foaming process will stop, and several studies have shown that there is a close relationship between the fineness of the ground product and the pore diameter of the glass foam. At the same time, the particle size of the foaming agent influences the formation and size of the pores. If the particle size of both the glass waste and the foaming agent falls within nearly the same or the same size range, the structure of the formed pores is more homogeneous (Fernandes, et al., 2013). 


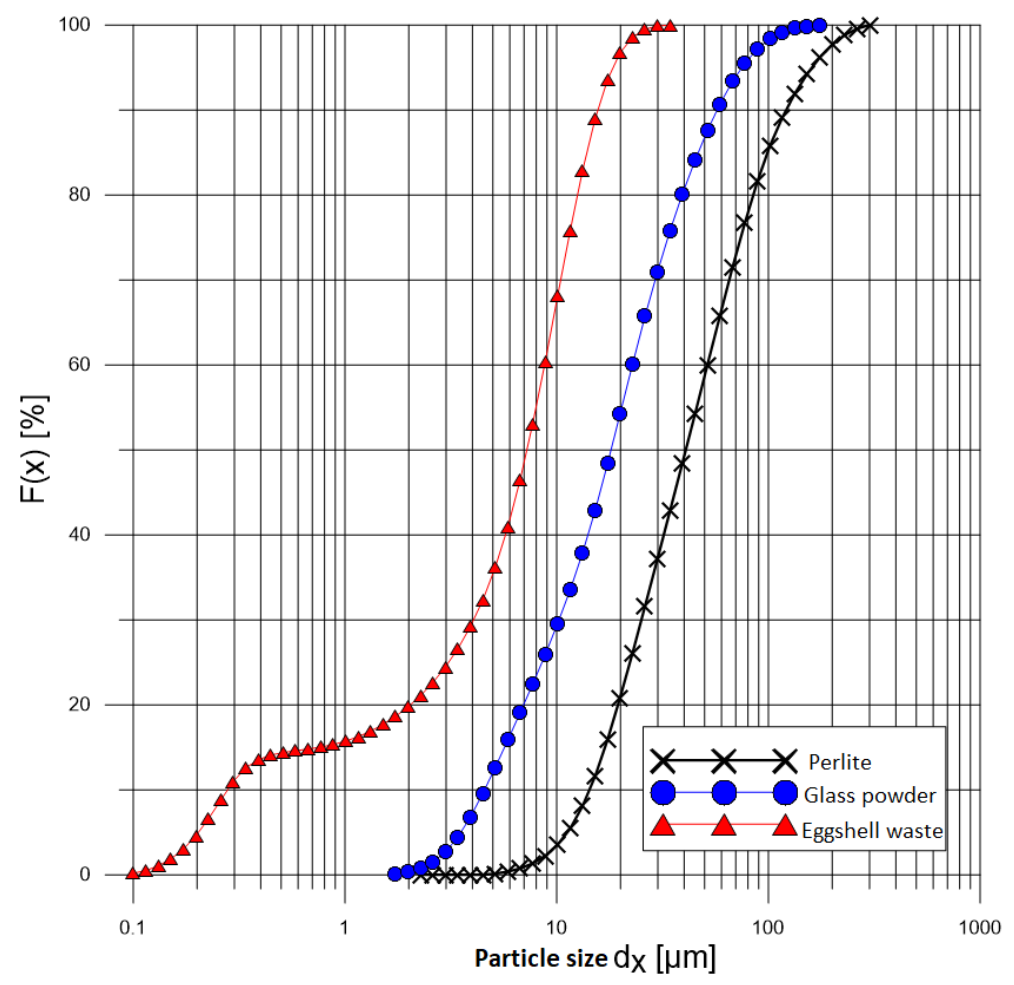

Figure 1. Particle size distribution of raw materials

Table 2. Median and $80 \%$ particle sizes of the raw materials

\begin{tabular}{|l|c|c|}
\hline Raw materials & $\mathrm{X}_{50}[\mu \mathrm{m}]$ & $\mathrm{X}_{80}[\mu \mathrm{m}]$ \\
\hline Eggshell waste & 7.78 & 7.22 \\
\hline Perlite & 40.70 & 84.8 \\
\hline Glass powder & 12.32 & 29.6 \\
\hline
\end{tabular}

\subsection{Sintering experiments}

Sufficient selection of heating temperature for the production of glass foam is essential since it is directly related to the viscosity of the glass and its expansion caused by the gas release from the foaming agent decomposition. The glass working range temperature is where the viscosity $\left(10^{6.6}-10^{3} \mathrm{~Pa} \cdot \mathrm{s}\right)$ is low enough to allows the expansion of the generated gases. The appropriate viscosity range for the glass foam production with maximum porosity is between $10^{3}$ and $10^{5} \mathrm{~Pa} \cdot \mathrm{s}$. This range correlates with temperatures between 800 and $1000{ }^{\circ} \mathrm{C}$ in the case of soda-lime glasses (Souza, et al., König et al., 2017).

For both cases (ESW- and P-tablets), the experiment has been divided into three main parts. (1) Primarily the appropriate temperature was selected, then (2) adequate foaming agent ratio, and lastly (3) the residence time in the furnace of the tablets. In case of $\mathrm{P}$, the heat treatment was carried out in the range of $800-1100{ }^{\circ} \mathrm{C}$, depending on its swelling temperature, from which the value of $1100{ }^{\circ} \mathrm{C}$ was finally selected. $0-100 \mathrm{wt} \%$ tablets were made according to the $\mathrm{P}$ content, of which $35-45 \mathrm{wt} \%$ was selected in further experiments. The residence time, in this case, was 35 minutes. 


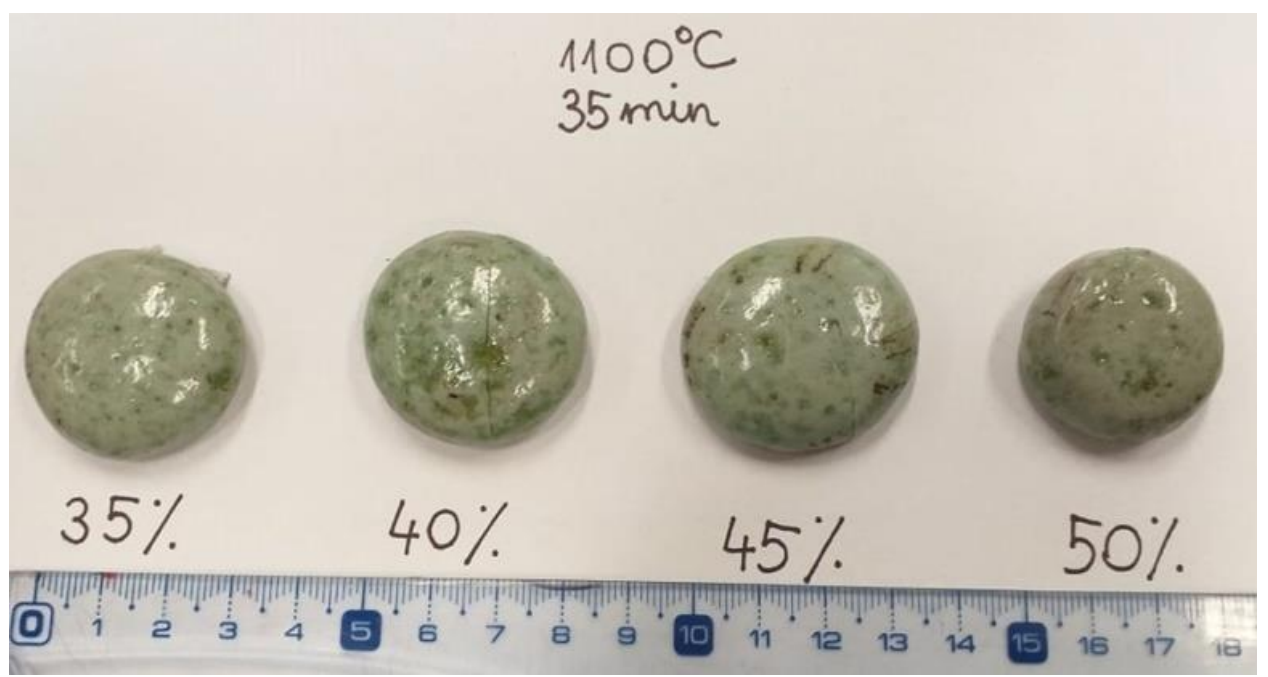

Figure 2. Glass foam tablets with different $P$-content

On these terms, ESW tablets were made in the range of $600-900{ }^{\circ} \mathrm{C}$, after which a temperature of $900{ }^{\circ} \mathrm{C}$ proved to be adequate. 1-30 wt \% tablets were prepared according to ESW content, from which the range of $1-10 \%$ was selected for further experiments. The residence time was 30 minutes, and the furnace heating time, which was 90 minutes.

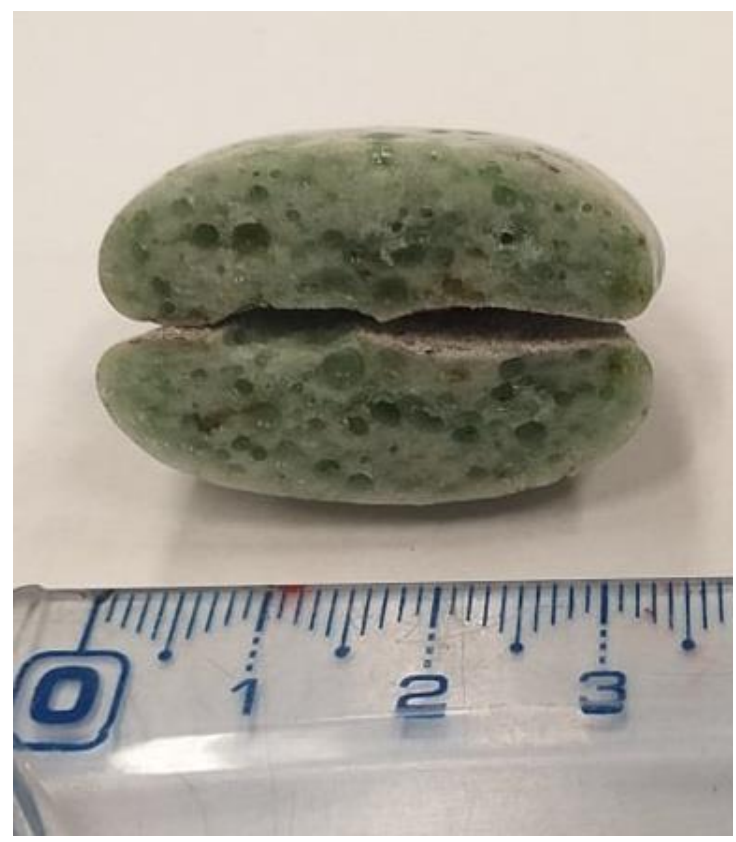

Figure 3. Pore structure of P-containing tablet (45 wt\% P-content) 


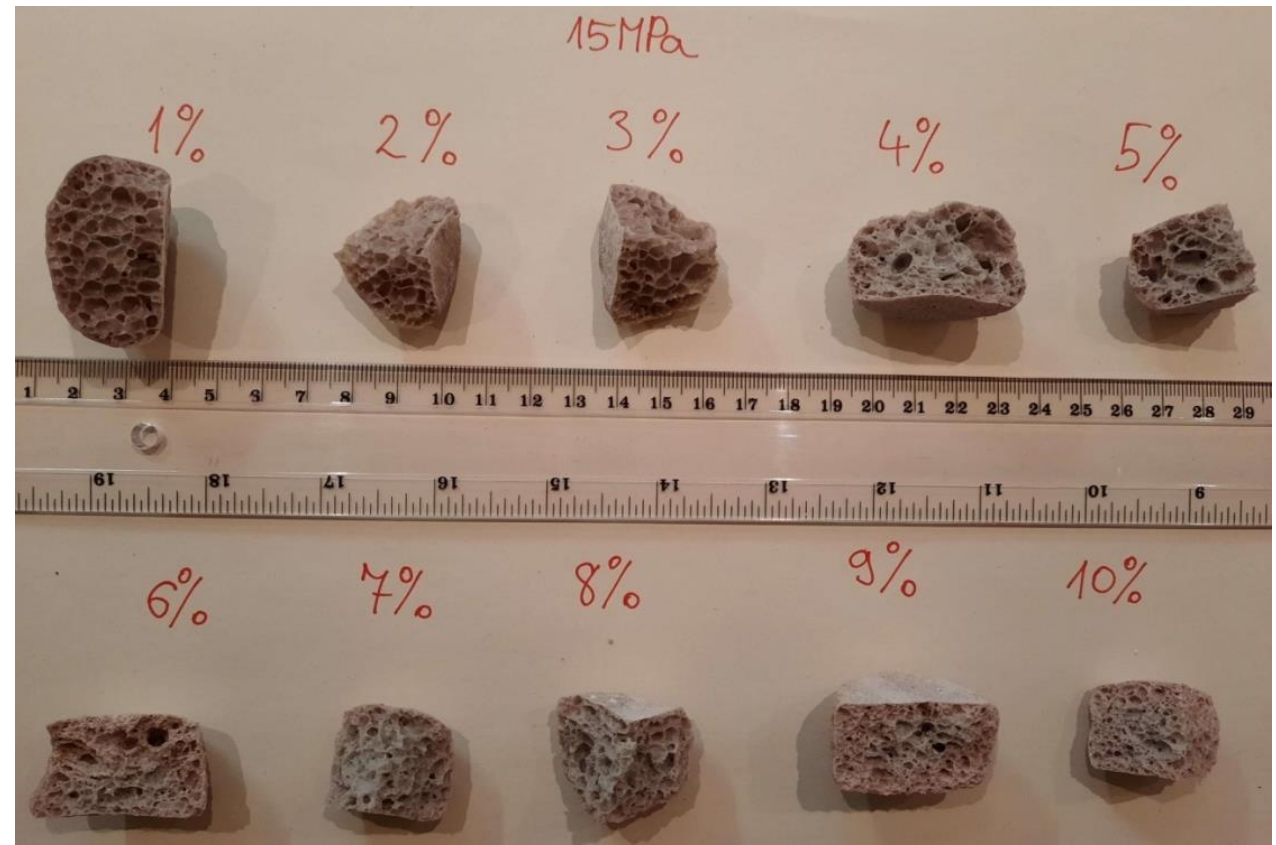

Figure 4. Glass foam tablets with different ESW-contents

\subsection{Density and porosity of glass foam}

Figure 5 and Figure 6 show the specimen density of glass foam tablets before and after heat treatment with different $\mathrm{P}$ and $\mathrm{ESW}$ content.

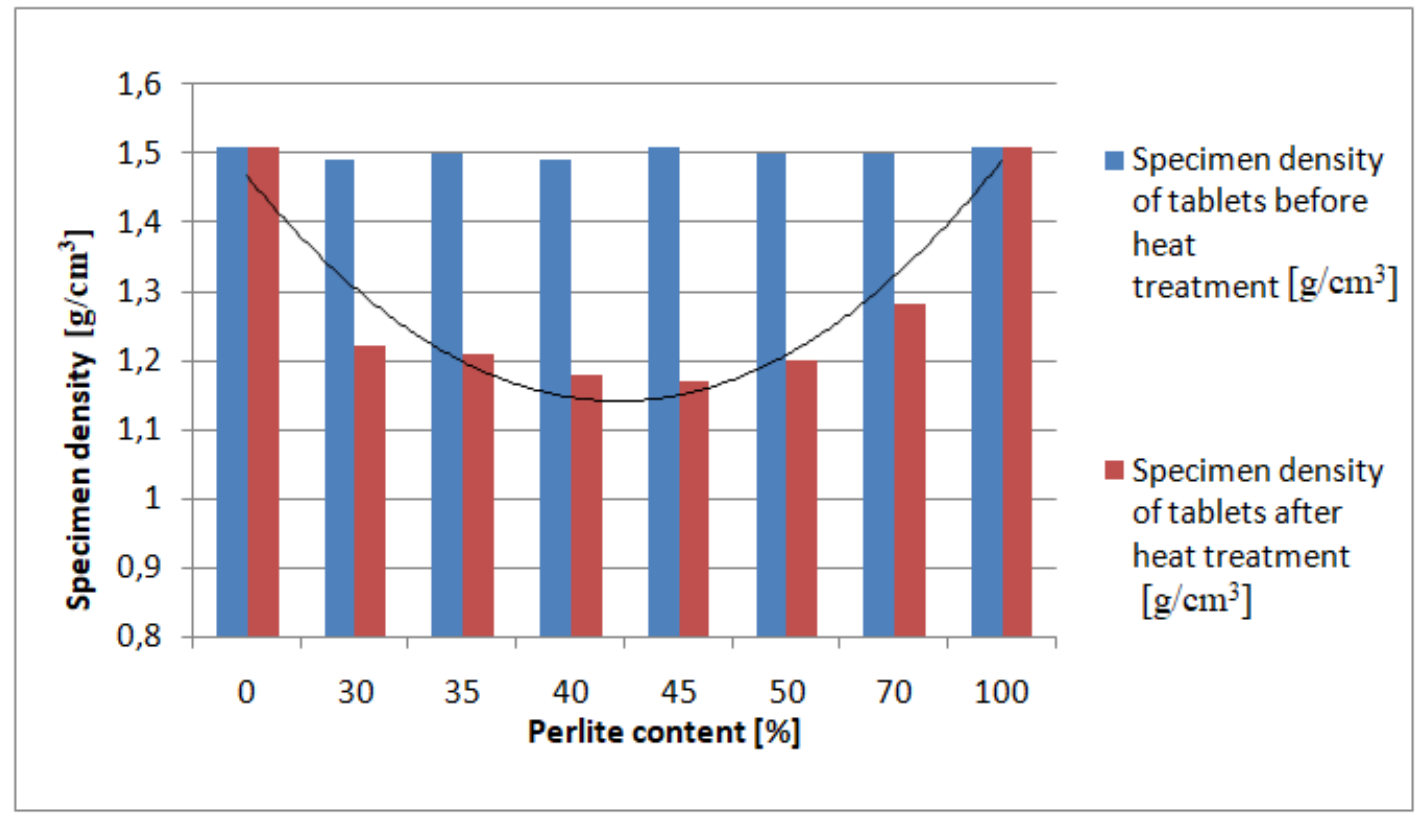

Figure 5. Density values of $P$-containing tablets before and after heat treatment 


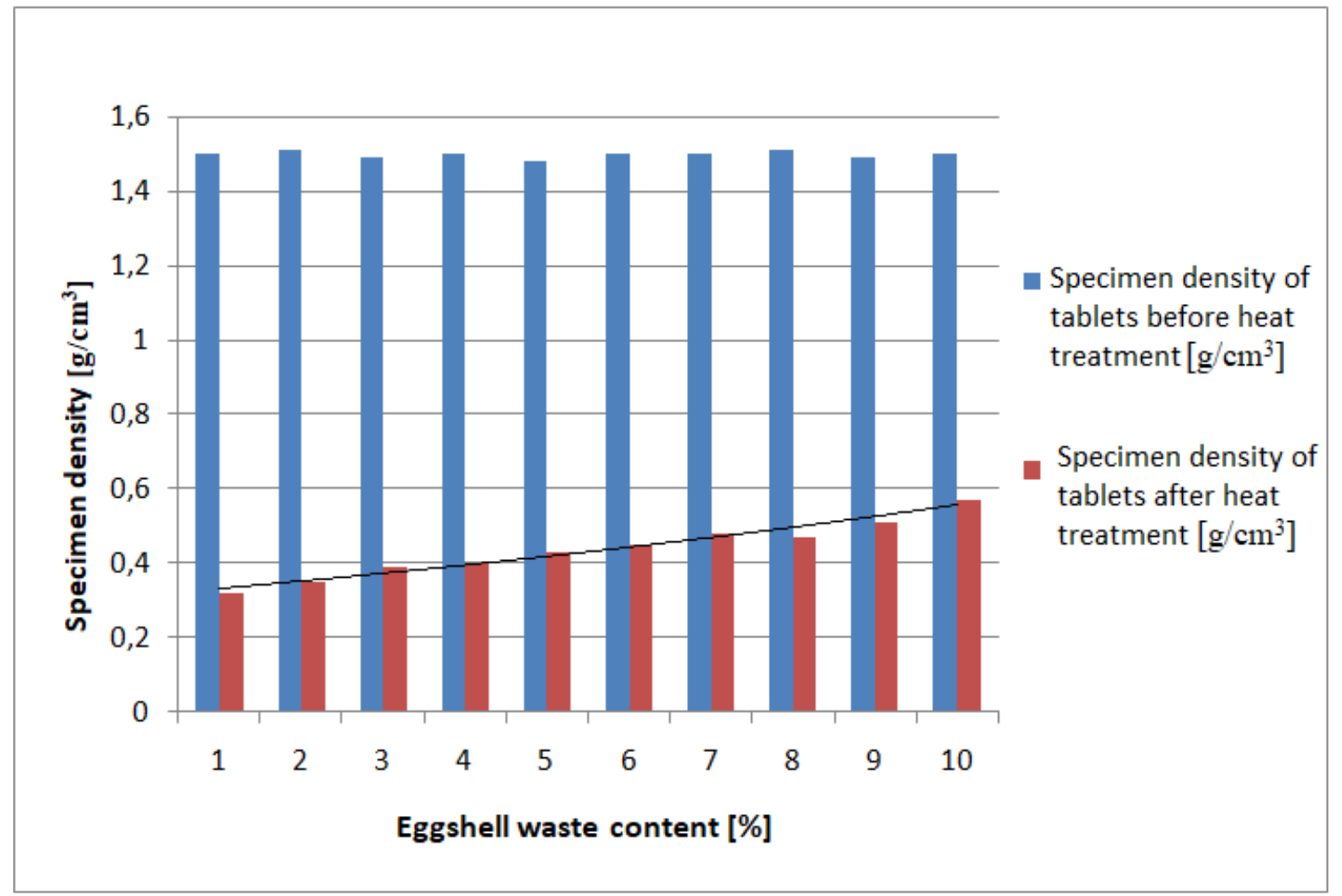

Figure 6. Density values of ESW-containing tablets before and after heat treatment

The density of the tablets before heat treatment was nearly the same range in P and ESW tablets. The maximum change in specimen density occurred at $45 \mathrm{wt} \% \mathrm{P}$ content, and $1 \% \mathrm{ESW}$ content, where the calculated porosities (Figure 6.) were the highest (P $56 \mathrm{wt} \%$, ESW $86 \mathrm{wt} \%$ ).

In the case of ESW based glass foam specimens, it can be observed that with the increase of the foaming agent content the value of density increases and the degree of porosity decreases. This is caused by the generated excess gases, which promote an increased internal pressure in the material, result in rupture of the pore walls (Bernardo and Albertini, 2006, König et al., 2015, Souza et al., 2017).

According to Scheffler and Colombo (2006) glass foams typically show porosity values higher than $60 \%$. Figure 7 shows that P-containing glass foams remain below this value however; ESW based specimens porosity values correspond to the literature value.

\subsection{Abrasion resistance of glass foams}

Figure 8 shows the abrasion values of P-and ESW-tablets. The maximum wear was observed for glass foam with $45 \% \mathrm{P}$ and $1 \% \mathrm{ESW}$ content. This is caused by the higher level of foaming because tablets with more porous structure are less resistant. 

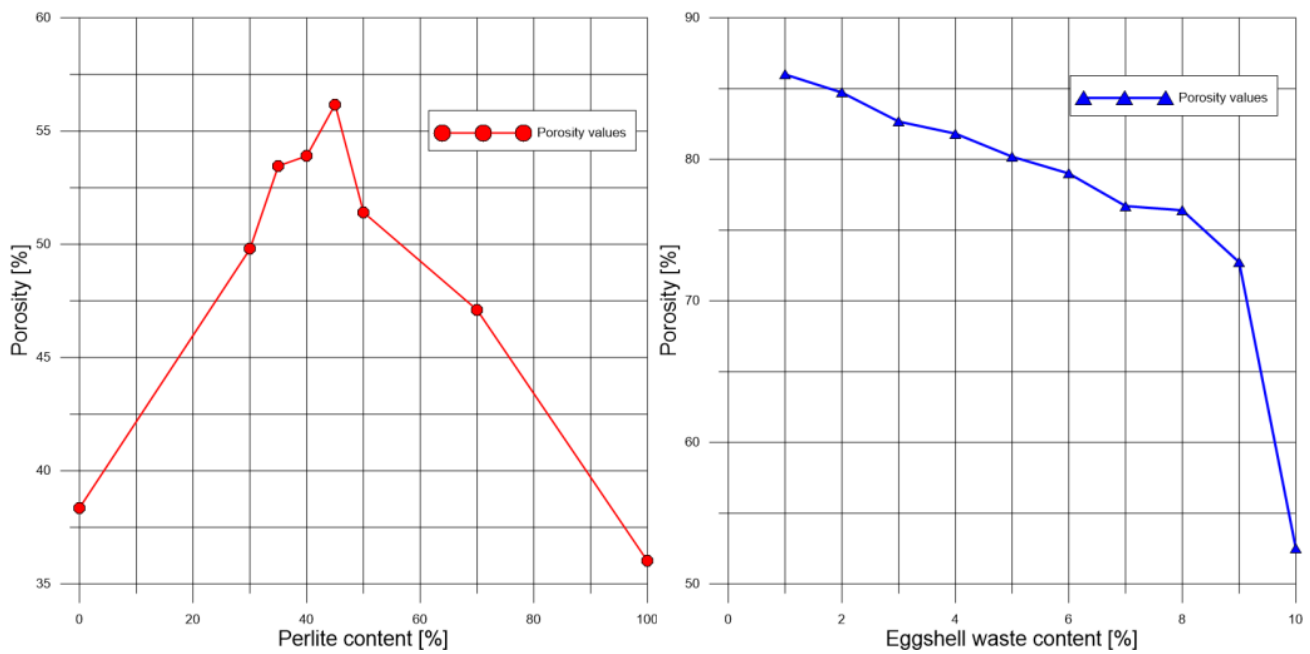

Figure 7. Calculated porosity values of P-and ESW-containing glass foam tablets
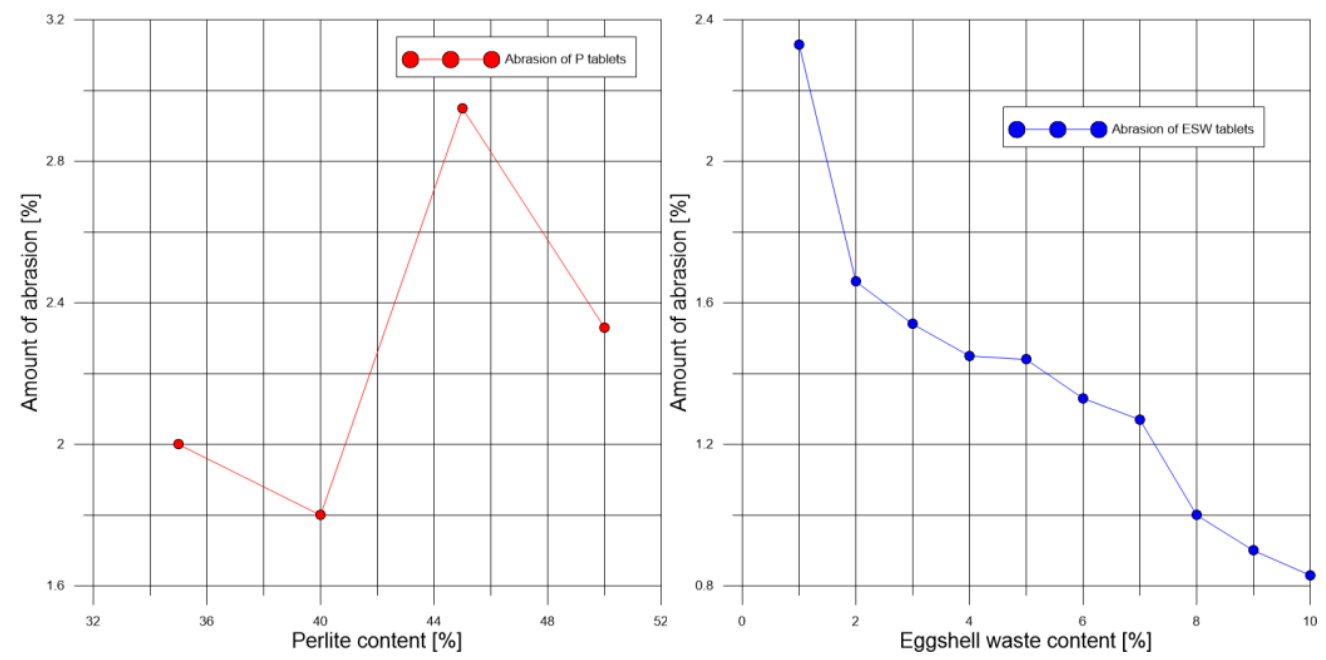

Figure 8. Amount of abrasion of P-and ESW-containing glass foam tablets

\section{Conclusion}

The density test results of P-glass foam tablets showed that a significant change in density was observed for tablets containing $45 \%$ of P. There was no change in density for tablets containing $0 \%$ and $100 \%$ perlite. In terms of porosity, the calculated values showed that $45 \%$ P-content had a higher porosity $(56.17 \%)$, but this value was below the average porosity for glass foams $(>60 \%)$.

The foaming agent particle size affects the cell size, which will influence the performance and characteristics of the foam glass. This in turn determines the density of the product. The larger the cell size resulted in the lower the product density.

Density measurements of ESW-glass foam tablets showed that tablets containing 1-10\% content had a relatively low density. The $1 \%$ ESW tablets had the lowest specimen density and the highest 
porosity (86\%). One of the most important factors in glass foams preparation, that the product should be a lightweight, porous material. The density and porosity values of ESW foamed tablets correspond to these terms.

In the case of specimen density values of ESW and P glass foam tablets, it can be observed that where is the maximum foaming occurred (1\% ESW-content), there is the lowest specimen density value. This is caused by the fact that the higher the cell size, the lower the product density (Salah et al.; 2007).

From the abrasion resistance test, it was found that the $45 \mathrm{wt} \% \mathrm{P}$ - and $1 \mathrm{wt} \% \mathrm{ESW}$-content tablets had the highest degree of wear.

However, foaming occurred in P-containing tablets, but based on the values obtained, it is a less effective foaming agent than ESW under the investigated circumstances. In addition, the temperature required for foaming with $\mathrm{P}$ is $1100^{\circ} \mathrm{C}$, while $900^{\circ} \mathrm{C}$ is sufficient for foaming with $\mathrm{ESW}$, which involves less energy investment.

\section{Acknowledgement}

The authors are grateful to Ferenc Móricz for the XRF measurement.

\section{References}

[1] Kálnai, G., Kálnai, M. (2007). Az üveghulladék gyüjtés, kezelés, hasznositás helyzete Magyarországon, Human-Szervíz Kutató- es Munkakörnyezetfejlesztő Kft.

[2] Scheffler, M., Colombo, P. (2006). Cellular Ceramics: Structure, Manufacturing, Properties and Applications https://doi.org/10.1002/3527606696

[3] Scarinci, G., Brusatin,G., \& Bernardo, E. (2005). Glass foams, 158-176. https://doi.org/10.1002/3527606696.ch2g

[4] Farkas, G. (2001). A korszerü perlitbányászat és előkészítés kialakulása és várható fejlődése. Miskolci Egyetem Közlemény A, Bányászat, 60, 17-34.

[5] Baláž, M. (2018). Ball milling of eggshell waste as a green and sustainable approach: A review. Advances in Colloid and Interface Science, 256, 256-275.

https://doi.org/10.1016/j.cis.2018.04.001

[6] Bernardo, E., Albertini, F. (2006). Glass foams from dismantled cathode ray tubes. Ceramics International. https://doi.org/10.1016/j.ceramint.2005.04.019

[7] Fernandes, H. R., Ferreira, D. D., Andreola, F., Lancellotti, I., Barbieri, L., \& Ferreira, J. M. F. (2014). Environmental friendly management of CRT glass by foaming with waste egg shells, calcite or dolomite. Ceramics International, 40(8), 13371-13379.

https://doi.org/10.1016/j.ceramint.2014.05.053

[8] Zhong, Y., Shaw, L. L., Manjarres, M., \& Zawrah, M. F. (2010). Synthesis of silicon carbide nanopowder using silica fume. Journal of the American Ceramic Society, 99, 3159-3167. https://doi.org/10.1111/j.1551-2916.2010.03867.x

[9] Li, J., Zhuang, X., Monfort, E., Querol, X., Llaudis, A. S., Font, O., Moreno,N., Ten,F. J. G., \& Izquierdo, M. (2018). Utilization of coal fly ash from a Chinese power plant for manufacturing highly insulating foam glass: Implications of physical, mechanical properties and environmental features. Construction and Building Materials, 175, 64-75.

https://doi.org/10.1016/j.conbuildmat.2018.04.158 
[10] Souza, M. T., Maia, B. G. O., Teixeira, L. B., de Oliveira, K. G., Teixeira, A. H. B., Novaes de Oliveira, A. P. (2017). Glass foams produced from glass bottles and eggshell wastes. Process Safety and Environmental Protection, 111, 60-64. https://doi.org/10.1016/j.psep.2017.06.011

[11] Fernandes, H.R., Andreola, F., Barbieri, L., Lancellotti, I., Pascual, M. J., Ferreira, J. M. F. (2013). The use of egg shells to produce Cathode Ray Tube (CRT) glass foams. Ceram. Int., 39(8), 9071-9078. https://doi.org/10.1016/j.ceramint.2013.05.002

[12] König, J., Petersen, R.R., Yue, Y., (2015). Fabrication of highly insulating foam glass made from CRT panel glass. Ceram. Int., 41(8), 9793-9800.

https://doi.org/10.1016/j.ceramint.2015.04.051

[13] Salah, M., El-Haggar, P. E. (2007). Sustainability of municipal solid waste management. Sustainable Industrial Design and Waste Management, 149-196.

https://doi.org/10.1016/B978-012373623-9/50007-1 